\title{
Foreign Experience of Financial Mechanism in Water Use
}

\author{
Kurbanov Daniyar Rozumbayevich
}

\begin{abstract}
This article presents Israel's experience of effective use of water resources. During the research, the following was investigated:

- Israeli government policies aimed at the rational use of water resources;

- the essence of Israeli policy on the rational use of water resources in agriculture;

- Use Israel's strategy to grow its water use and price;

- Long-term forecasting system for water use.

The study concluded that:

Prudent water management, reuse of wastewater and desalination of sea water, as well as the construction of the AllIsrael Water Pipeline, a consistent economic policy in the water sector against the background of effective integrated management of limited water resources, aimed at combating their scarcity, allowed to solve the problem of water shortage on a national scale and take the country out of the water crisis, reduce climate dependence and preserve the Lake of Kineret.
\end{abstract}

Keywords. Israel, water resources, rational use of water resources, Israeli water model, water resources.

\section{INTRODUCTION}

Financial and economic mechanisms are the most important means of ensuring the activities and development of any industry, any enterprise. Moreover, the effectiveness of activities is largely determined by how correctly defined these mechanisms are and how clearly they are used. This, of course, applies to water management, both in the field of operation and in the field of development, including new construction, reconstruction, environmental protection, etc. But in the water sector, these mechanisms are another important one - they must regulate water requirements and stimulate water conservation.

In world practice, there are no unified approaches to setting water use fees for various categories of water users. Almost everywhere, paid water use is carried out as a reimbursement of costs associated with the formation, transportation and distribution of water between water users, as well as a factor contributing to the improvement of water resources management and their rational use in the interests of the whole society. Reimbursement of water costs is realized in various forms:

payment for the consumption of water;

payment per unit of water use (person, user, irrigated hectare, etc.);

fee for exceeding the water limit;

payment for water pollution;

sale of the right to water (license fee);

enterprise tax, including water charges;

stock ownership of water.

Revised Manuscript Received on 14, October 2019.

Kurbanov Daniyar Rozumbayevich, Independent researcher of the Banking and Finance Academy of Uzbekistan.
Almost everywhere, the highest payment for water comes from industrial and municipal water supply, which fully covers the share of water management costs for their maintenance. Irrigation water consumers, due to state subsidies to cover water costs, are in a privileged position. In developing countries, where paid water is at the initial stage, incentive measures are applied for irrigation water consumers in the form of:

agricultural market liberalization;

preferential lending to farmers;

preferential taxation;

attracting paid labor of water users to the maintenance of water facilities.

The development of water management, large-scale water management, land reclamation is carried out with the full financing of the state, sometimes with the involvement of local budgets and land users. The following general principles can be noted:

most countries set the price of water for industry and municipal consumption, taking into account the selfsustainability of systems, plus a certain share of profit

in most countries of the world, a block-rising price system has been introduced, in which the payment within the required strict norm is carried out at the lowest price, and as the water intake increases, the price progressively increases; agricultural and municipal water supply mainly pays off.

Israel is the world leader in the processing and recycling of wastewater in agriculture - about $86 \%$ of all wastewater in the country is used for this. For comparison: the country next to us - Spain - uses only $17 \%$ of secondary water, and as for the USA, only one percent of water is reused there (1, Goldrich). Referring to these figures, the influential American newspaper The New York Times calls Israel the "desalination superpower." Israeli experts are pioneers of agricultural biotechnology drip irrigation, soil solarization, widely use industrial effluents for agricultural needs. The total number of irrigated lands has increased from 30,000 hectares in 1948 to 255,000 today. So, drought is no longer threatening Israel. Today, such extreme measures are no longer necessary, but most of our compatriots still spend water very carefully. The total potential of water resources in Israel is from 1.8 to 2.1 billion cubic meters of water. The annual demand of the country reaches 2.5 billion cubic meters. The per capita water resource indicator in Israel is one of the lowest in the world (160 m3 / year per person). Despite this, the country was able to fully satisfy the growing needs of the economy in water resources. Today, only half of all water consumed by Israelis comes from

Published By:

Blue Eyes Intelligence Engineering 
natural sources. The second half is extracted artificially: by recycling and desalination. Israel is a leader in the production of fresh water from the sea. There are six desalination plants in Israel: Ashkelon, Palmahim, Hadera, Sorek, Ashdod and Eilat. (2, Orizansky).

The Israeli experience of rational use of water resources, economic and agricultural policy of the state on rational use of drinking and salt water was analyzed, as well as widely used and widely used such methods as analysis and synthesis, induction and deduction to increase the efficiency and accuracy of scientific research.

\section{THE EXTENT TO WHICH THE SUBJECT IS STUDIED}

Israel's rational use of water resources and agricultural development as a developed industrial and agrarian country has been shaped by scientific research and has been effectively studied by every country experiencing water shortages in the world economy and their researchers.

In particular, NirBecker's article "Value of moving from a central planning to a market system: lessons from the Israeli water sector" (3, Becker) Transforming the agricultural water distribution system in Israel from a water distribution system to different users and investigates the effects. A model of mathematical planning is used throughout Israel, where 'optimal' water allocation is available and comparable.

The results of the model are used to find out the cost of different ponds in Israel (about eight). These prices can then be used to grant property rights to water users to ensure rational water use, as their rights can now be purchased from the source. The implication is clear in relation to any possible move to the market system in any other sector. From the secondary prices, we can predict the equilibrium prices and their effects for different users. The central government does not have to intervene in market mechanisms, as it is shown that each farmer can sell or exercise his rights. Since participation in the market is voluntary, every farmer makes decisions individually and socially. However, in the transition from central planning to market mechanism, the government has another task, which is to give property rights to market development. Initial allocation does not guarantee that decentralization of the system will benefit all regions, but at least part of the problem should be solved across regions.

The results show that without capital expenditure, \$28 million in revenue can be earned from the budget and \$ 64 million when they are included.

According to a study conducted by Dan Yaron (4, Yaron) from 1970 to 1980 , some of the existing relationships between irrigation economics, institutional frameworks and water pricing systems have been examined. This means increased pressure to adapt institutional and price systems for more rational use in the context of a conceptual understanding of irrigation water shortages and economic relations with irrigation. The key aspects of the development of two interrelated areas in Israel since 1950 are reviewed and briefly discussed.

\section{RESEARCH METHODOLOGY \& RESULTS}

In more than a hundred studies, we can see the Israel water efficiency analysis.

\section{RESEARCH AND ANALYZES}

The volume of water was estimated in the middle of the twentieth century. in the region of 3 billion $\mathrm{m}^{3}$ per year. Analysis of data for the period from 1976 to 2009 showed (5, Tsur) two features of the water resource of Israel: high temporal fluctuations and a tendency to decrease. The downward trend averaged 8.92 million $\mathrm{m}^{3}$ per year and may be the result of climatic changes, and the temporary fluctuations of fresh explosives during this period ranged from 4 million $\mathrm{m}^{3}$ to 900 million $\mathrm{m}^{3}$ with an average value of 1,547 million $\mathrm{m}^{3}$ / year. A series of consecutive dry years since 1993 has made adjustments to the volume of WWR. According to the Israeli Hydrological Service (6, Weinberger), the volume of fresh water resources currently stands at 1,451 million $\mathrm{m}^{3}$ / year. A total of 325 million $\mathrm{m}^{3}$ per year of additional losses are due to water that seeps into the ground and drains into the sea, rather than seeps into the ground to reach the aquifer. Given these losses, only 1,100 million $\mathrm{m}^{3} / \mathrm{h}$ of fresh water are available for use. It is assumed that 100 million $\mathrm{m}^{3}$ / year of brackish water can be further processed to a fresh state and bring the available volume to the Israeli water sector to 1200 million $\mathrm{m}^{3}$ of fresh water.

Figure 1.

The amount of water resources in Israel

\begin{tabular}{|l|l|l|l|l|}
\hline Years & $\begin{array}{l}\text { Total drinking } \\
\text { water,\% }\end{array}$ & Purified water, \% & Brine, \% & Million m3 \\
\hline 2000 & 67 & 24 & 9 & 1089 \\
\hline 2010 & 48 & 38 & 14 & 1045 \\
\hline 2015 & 45 & 43 & 12 & 1083 \\
\hline 2020 & 42 & 47 & 11 & 1138 \\
\hline 2025 & 39 & 51 & 10 & 1156 \\
\hline 2050 & 26 & 67 & 7 & 1450 \\
\hline \multicolumn{2}{|l}{ *The table is formed by the authors }
\end{tabular}

The total water reserves in Israel can be divided into two natural water sources: surface and underground. There are few surface waters, since Israel does not have large rivers, and those that are available, most of them are intermittent or completely dry throughout the year.

Water conservation is the most reliable and least expensive way to expand the country's water resources, and this task is being implemented in all sectors. In order to reduce consumption and raise awareness of water scarcity, public water conservation campaigns are being used in combination with technical and economic measures. Israeli agriculture currently consumes $58 \%$ of the country's water resources (around the world this figure is 70-90\%). Significant savings in the agricultural sector were achieved through technological improvements in irrigation methods, including sprinkling, drip irrigation with computerized and automated control systems, as well as the reuse of fresh water and wastewater treatment.

Irrigation in Israel is combined with water and chemical training in irrigation. This method will increase soil fertility and productivity. 
Water prices will increase depending on the quantity used. That is, starting prices up to a specified amount of water are used when prices increase with increasing use.

Water prices were set by the block system. For each consumer, quotas were set for both municipal water consumers and agricultural. For agricultural producers, the government severely controls what type of product and how much each farm produces. Such a policy is carried out in order to avoid overproduction, and hence excess water consumption. Depending on the volume of production and the type of crop produced, each farm receives a certain annual quota for water. The minimum price for an agricultural consumer is 50 US cents per $\mathrm{m}^{3}$; it is set only for half of the water consumed under the allocated quota. The next $30 \%$ of the quota is paid already at 60 cents $/ \mathrm{m}^{3}$, the rest - at 75 cents $/ \mathrm{m}^{3}$. The treated wastewater costs 35 cents / $\mathrm{m}^{3}$ for irrigation, and weakly saline 24 cents $/ \mathrm{m}^{3}$. Thus, agricultural producers are motivated to spend water more efficiently than is laid down in the regulations of the Ministry of Agriculture. Separate tariffs exist for industrial enterprises. About $30 \%$ of the total water currently consumed in the industrial sector is brackish rather than fresh water. Incentives are provided for the use of alternatives to drinking water, such as lowering the rates for the purchase of brackish $\left(\$ 0.3 / \mathrm{m}^{3}\right)$ rather than drinking water $\left(\$ 1.3 / \mathrm{m}^{3}\right)$. Tariffs for domestic water supply are as follows (2011): - up to $3.5 \mathrm{~m}^{3}$ per person per month - the rate is $2.5 \mathrm{USD} / \mathrm{m}^{3}$ - above $3.5 \mathrm{~m}^{3}$ per person per month the rate is 4 USD $/ \mathrm{m}^{3}$. In 2010, water tariffs in the municipal sector were increased by $40 \%$ and preferential $\mathrm{m}^{3}$ of drinking water began to cost $\$ 2.6$, which led to a decrease in water consumption in this sector to $18 \%$.

Advanced technologies make it possible to maximize the use of each cubic meter of water. Thus, the use of a closed water supply system in fisheries can not only save water, but also completely automate the process: computers that monitor the chemical composition of the water, if necessary, provide fresh water, specialized fans that allow the fish to breathe, sensors that constantly establish and analyze the state of the fish in pools.

The farm grows up to $100 \mathrm{~kg}$ of fish per $1 \mathrm{~m}^{3}$ of water even in the desert. In crop production, salt water is used without preliminary water treatment, taking into account the biological characteristics of plants and the use of various technological methods to increase salt tolerance.

In the driest region of Israel, in the Arava Valley, where the annual rainfall is less than $50 \mathrm{~mm}, 32$ million $\mathrm{m}^{3}$ of brackish water per year is used in crop production. About $30 \%$ (46 million $\left.\mathrm{m}^{3}\right)$ of total water $\left(138\right.$ million $\left.\mathrm{m}^{3}\right)$ consumed in the industrial sector is brackish. Over 60 years, total water consumption in Israel has increased by $60 \%$, in agriculture by only $10 \%$, and in industry within $1-2 \%$. The increase in water use over this period is due to a population growth from 2 million people in 1958 to 8.4 million in 2017 (8, Central Bureau of Statistics). In Israel, the average annual per capita water consumption over the past 15 years has decreased by $22 \%$ : from $110 \mathrm{~m}^{3}$ in 1998 to $86.8 \mathrm{~m}^{3}$, the end of 2014. And although water demand per capita is falling, in absolute terms still growing. Currently, the urban sector consumes approximately 740 million $\mathrm{m}^{3}$, an annual increase of approximately 20 million $\mathrm{m}^{3}$ annually, an increase of about 4\%. According to Mekorot's plans, the Israeli population will increase to 9.1 million $\mathrm{m}^{3}$ by 2020 , and water consumption in the urban sector will approach 1 million $\mathrm{m}^{3}$, and by 2050 it will exceed the volume of water consumption in agriculture. Thus, there will be a redistribution of natural water from agriculture to the household sector. In 2003, the Environmental Law was added to the list of legitimate recipients of fresh water in the Law on Water. For the rehabilitation of water sources (rivers, reservoirs, groundwater), 10 to 50 million $\mathrm{m}^{3}$ of fresh water are allocated per year. The restoration of Israeli rivers is already becoming a reality $(9, \mathrm{Tal})$.

The Water Resources Authority is considering the construction of a water conduit that will pump desalinated water from the Mediterranean Sea into Lake Kinneret, which is rapidly shallowing due to prolonged drought. According to plans, in dry years, 100 million $\mathrm{m}^{3}$ of desalinated water will be pumped to Kinneret, which will increase the water level in the lake by $70 \mathrm{~cm}$.The planning range is long - until 2050 (10, Long-Term Master Plan for the National).

The formation of a long-term water balance does not pretend to be an accurate forecast of the future and will be periodically reviewed taking into account technological, demographic, geopolitical and other changes. For the basic indicators of the water balance, data for 2010 with reference points in 2020 and 2030 were taken. Moreover, it is assumed that the population in 2020 will increase to 9.1 million people, in 2030 - up to 10.9 million, and in 2050 15.5 million people (an annual increase of $1.8 \%$ ), and water consumption per capita will drop from $100 \mathrm{~m}^{3}$ in 2010 to 95 $\mathrm{m}^{3}$ in 2050 .

Development policies and balances were determined on the basis of existing agreements with Jordan and the Palestinian Authority. The provision of additional volumes of water, as well as future agreements with Syria and Lebanon, will require both the improvement and expansion of the desalination system, along with additional investments in water transportation and distribution systems. The planned target for the operational reserve, which will guarantee the formation of the average volume in natural reservoirs with a security of $90 \%$, is about 1,500 million $\mathrm{m}^{3}$ above the "red line". It is based on statistical data that in $90 \%$ of cases the total use of accumulated water will reach approximately 1,500 million $\mathrm{m}^{3}$ if a volume equal to the average replenishment is formed each year. This is a guarantee to maintain a water-free level of consumption. Due to the created surplus, the reserves of underground and surface water sources will be replenished with a view to their rehabilitation.

Desalination "revolution" allowed to completely stop the pumping of water from Lake Kineret to restore its level and reduce the salinity of the reservoir. 
Moreover, the created surplus of water resources will make it possible to increase water supplies to the urgently needy neighboring Jordanian Kingdom and the Palestinian Authority. The development of Israel's water sector requires significant investments, both from the state budget, and attracting private, including foreign, investments. To implement this plan, the level of investment in obtaining alternative water resources, the rehabilitation of natural water resources and the water supply infrastructure will require about 206 billion shekels, or about 5.15 billion shekels annually, until 2050. About $80 \%$ of this amount will be financed by water consumers due to rising water prices. In an era of impending water scarcity, water ceases to be a free resource and becomes a commodity for which you have to pay either to water-supplied neighbors who control fresh water sources, or invest in your own water-saving technologies. The third way is to replace a scarce resource with a scarce one. Israel used wastewater and sea waters as well as intellectual baggage of its compatriots, who were able to lead Israel into leaders in the efficient use of limited water resources as a non-deficient resource.

\section{CONCLUSION}

One of the major factors influencing Israel's economic development is the fact that fresh water use in the country is in line with the strategic plan.

The development of such industries as pharmaceuticals, cosmetology in the country, the provision of $95 \%$ of the country with local food and fruit exports, and the development of agrarian tourism are the result of the country's water management policy.

With the decline of fresh water in the world economy, the increase in fresh water in Israel is due to the use of research and development results in the land reclamation and irrigation systems.

\section{REFERENCES}

1. Goldreich, Y. (2003). The climate of Israel observation, research and application. New York: Springer Science and Business; 2003. 264.

2. Oziransky, Y., Kalmakova A., G., Margolina, I. L. (2014)Integrated Management of limited Water Resources for sustainable water supply of arid regions. (Experience of Israel). Arid Ecosystems. 2014; 20(4):5765

3. Becker, Nir (1995). Value of moving from central planning to a market system: lessons from the Israeli water sector// Agricultural Economics//Volume 12, Issue 1, April 1995, Pages 11-21

4. Yaron, Dan. (1979). Economics of irrigation and the institutional and pricing systems of water in Israel// Agricultural Water Management Volume 2, Issue 3, November 1979, Pages 203-216

5. Tsur, Y. (2014). Closing the (widening) gap between natural water resourses and water needs in the Jordan River Basin: A long term percpective. Departament of Agricultural Economics and Management, The Hebrew University of Jerusalem, Discussion Paper. 2014;2(14): 28.

6. Weinberger, G., Livshitz Y., Givati A., Zilberbrand M., Tal A., Weiss M., and Zurieli A. (2012). The natural water resources between the Mediterrarean Sea and the Jordan River. Israel Hydrological Servise, Israel's Authority for Water Sewage. 2012;1: 71.
7. Stanhill, G. (1992). Irrigation in Israel: past achievements, present challenges and future possibilities. In: Shalhevet J. et. Aii. (Eds.). Water Use Efficiency in Agriculture. Rehovot: Priel Publisher; 1992. P. 63-77.)

8. Central Bureau of Statistics. (2016) . Israel in Fugures. Available from: http://www.cbs.gov.il/www/publications/isr_in_n16e.pdf

9. Tal, A., Katz, D. (2012). Rehabilitating Israel;s streams and rivers. Int. Jour. River Basin Management. 2012;10(4): 317-330.

10. Long-Term Master Plan for the National.(2012). Water Sector, Part A - Policy Document. Israel Water Authority: 2012;4:102.

11. Orlovsky, N.S., Zonn, I.S. (2018). Water Resources of Israel: Trackrecord of the Development. Post-Soviet Issues. 2018;5(1):8-36. (In Russ.) https://doi.org/10.24975/2313-8920-2018-5-1-8-36. 